\title{
Biochar application for the improving soil fertility and paddy production on two systems of planting
}

\author{
Antonio Sipayung*, Tengku Sabrina, and Revandy Damanik \\ Faculty of Agriculture, Universitas Sumatera Utara, Indonesia
}

\begin{abstract}
A product of pyrolysis of residual biomass called biochar has several benefits into soil. Bio-charcoal formed by burning organic waste which will produce activated carbon and organic carbon and will be added to the soil. The purpose of this study was to evaluate biochar ability to improve soil fertility and increase the production of paddy crops with two planting systems. Legowo planting system is intermittent cropping between two or more rows of rice plants and one empty row. The research was conducted in Tanjung Garbus's Village, Deli Serdang District with an elevation of \pm 50 Meters above sea level. This research used a Factorial Split Plot Design with two factors that was treatment of planting systems as main plot (S), consist of 2 (two) stages: Jajar Legowo 2:1 and Jajar Legowo 4:1 and the sub-plot was biochar application (B) consisting of 3 levels namely, without biochar application, 25.5 ton/ha, and 50.5 ton/ha. The results showed that planting system significantly affected shoot wet weight and shoot dry weight and biochar application had a significant effect on shoot wet weight and no significant effect on shoot dry weight. The interaction showed no significant effect on all parameters.
\end{abstract}

\section{Introduction}

Paddy is one of the main food crops and as a staple food for almost all of Indonesia's population and highly paid attention to productivity. However, the problems faced today are:(1) the problem of the increasingly narrow land area,(2) the decreasing rice field quality,(3) the difficulty of opening new land, and (4) the effect of climate change [1].

Paddy is a major food commodity that has a strategic role. Paddy field crop is a food crop that after going through various processes will produce rice. Rice is a staple food that is vital for everyone. That is why efforts to meet the needs of rice continue to be done the through various program, one of them is by intensification. Intensification of paddy with the intake of chemical fertilizers in large quantities and in the long term, as well as the use of organic materials in wetland rice production system has resulted in disturbed soil nutrient balance resulting in decreased quality of land resources [2].

The location of rice planting is in the village ofTanjung Garbus Kampung, Ujung Pertanian sub-village, Deli Serdang district. Based on the result of soil analysis at Socfindo Laboratory (2016), it is found that soil $\mathrm{pH}$ was 5.3 and the C-Organic soil content was $1.73 \%$ where the ideal soil condition for C-Organic is $3 \%$. This means that soil fertility 
conditions on the research location was not in good conditions and needs to be done application of biochar to increase the productivity. These were evidenced by the yield of rice crops in two seasons of planting only 5 tons of grain with the use of inorganic fertilizer Urea fertilizer $150 \mathrm{Kg}, 150 \mathrm{~kg}$ NPK, SP-36 $150 \mathrm{~kg}$, ZA $150 \mathrm{~kg}$ and yield of 4.8 tons of grain by using fertilizer inorganic amount of $100 \mathrm{Kg}$ urea fertilizer, SP-36 $200 \mathrm{Kg}$, ZA 150 $\mathrm{Kg}, \mathrm{KCl} 50 \mathrm{Kg}$

The use of biochar is a new thing for the agricultural world particularly for paddy by utilizing biological charcoal formed from burning which will produce activated carbon, containing minerals such as calcium $(\mathrm{Ca})$ or magnesium $(\mathrm{Mg})$ and organic carbon and will be added to the soil. According to the research from the International Rice Research Institute (IRRI), biochar feeding on upland rice production in northern Laos increases topsoil hydraulic conductivity or surface layers', and improves the response of plants to fertilizer with nitrogen content [3].

Biochar can affect changes in the carbon cycle and $\mathrm{CO}_{2}$ emissions through changes in characteristics of soil and microbial. In fact, biochar itself can be decomposed through microbes to some extent on the ground [4]. Using meta-analysis [5]. found that incorporation of biochar to soil increased crop productivity by an estimated $10 \%$, however, yields from soil layers, land-processing practices plant experiments, and biochar feedstocks. The level of fertility of paddy fields in Indonesia was decreasing about $65 \%$ of the 5 million hectares of irrigated wetland have less than $2 \%$ organic matter while in normal condition the fertile land usually contains the cultivation of land, irrigation system and the return of organic material. In the paddy field, the most important source of organic material is the residual crop that has been harvested where the decomposition process occurs and organic material reshuffle. The rest of the harvest in the form of rice husk is the best source of organic material for soil fertility after decomposition process. [6].

Legowo row planting system is a cropping system that takes care of the crops', legowo row planting system is intermittent cropping between two or more rows of paddy field and one empty row. The advantage of the legowo row planting system is to make all plants or more plants become peripheral plants. Plants will get more sunlight and better air circulation, more nutrients, and easier maintenance of plants [7].

In principle the system of planting row legowo is to increase the population by adjusting the spacing. This planting system also manipulates the layout of plants, so that the clumps of crops are largely into peripheral plants. Rice plants located on the edge will get more sunlight, resulting in higher grain with better quality. In the legowo 2: 1 way of planting, every two rows of plants interspersed with an empty line with a width of twice the range of the row, but the spacing in the row is narrowed to half the original spacing [8].

Legowo 4: 1 planting system type 1 is a legowo cropping pattern with the whole line getting the insertion plant. This pattern is suitable to apply to less fertile land conditions. With this pattern, the plant population reached 256,000 clumps/ha with a population increase of $60 \%$ compared to the tile pattern $(25 \times 25) \mathrm{cm}$ [9]. Legowo $4: 1$ planting system type 2 is a cropping pattern by simply providing additional plant inserts on both rows of edge crops. The population of plants is $170,667 \mathrm{clumps} / \mathrm{ha}$ with the percentage increase of only $6.67 \%$ compared to the tile pattern $(25 \times 25) \mathrm{cm}$. This pattern is suitable to be applied to locations with high soil fertility. Even the absorption of nutrient by more plants. However, because the plant is more robust so as to minimize the risk of lumber during growth [9].

\section{Research Method}

This research was conducted in Tanjung Garbus Village, Sub-district of Pagar Merbau, Deli Serdang Regency. This research was conducted from December 2017 to March 2018. Paddy variety used were Inpari 33. The Seed was germinated, and after 21 days, they were 
planted in the experimental field. All treatment application used NPK fertilizer $45 \mathrm{~kg} \mathrm{~N}, 60$ $\mathrm{kg} \mathrm{P} 2 \mathrm{O} 5$ and $50 \mathrm{~kg} \mathrm{~K} 2 \mathrm{O}$ per hectare.

This research used Split Plot Design with two factors and four replicated $(n=4)$. Namely, the main plot was planting system consists of two treatments (S1): Legowo 2: 1, (S2): Legowo 4: 1 (S2). Subfactor: Biochar application consisting of 3 levels: without biochar application, (B1): 25.5 ton/ha Biochar, (B2): 50.5 ton/ha Biochar. Parameters were shoot wet weight and shoot dry weight.

Legowo 2: 1 row planting system has two lines of cropping with 1 lane removed. Distance between rows of plants $25 \mathrm{~cm}$ and distance between plants $12.5 \mathrm{~cm}$ and distance between lines is $50 \mathrm{~cm}$. while the system of planting row legowo 4:1 has a sense of four paths of cultivation with a path that is removed. Distance between rows of plants $25 \mathrm{~cm}$ and distance between plants $25 \mathrm{~cm}$ and distance between lines is $50 \mathrm{~cm}$.

Stages of rice cultivation 1. Land preparation, 2. Application of biochar to paddy fields 3. Selection of varieties and nurseries, 4. Planting (two systems of planting legowo 2: 1, and jajar legowo 4: 1) 5. Watering, 6. Fertilization, 7. Weed control, 8. Pests and diseases control, 9. Harvest.

All data were reported as means and standard deviation (SD) of the means. Analysis of variance was used to determine the statistical significance of the biochar treatment effects on planting system. Post hoc comparisons were made using least significant difference (LSD) test, with the criterion for statistical significance being set at $\mathrm{P}<0.05$. Pearson correlation was applied to analyze the correlations between the biochar and planting systems at the $5 \%$ and $1 \%$ levels of significance.

\section{Result and Discussion}

\subsection{Shoot Wet Weight}

Tabel 1 The comparison between main plot (two plant systems) to subplot (biochar application B0/Control).

\begin{tabular}{|l|l|l|l|l|}
\hline \multirow{2}{*}{ No } & \multicolumn{1}{|c|}{ Plant Systems } & \multirow{2}{*}{ Average } & S1 Legowo 2:1 & \multicolumn{1}{c|}{ S2 Legowo 4:1 } \\
\cline { 4 - 5 } & & & 4.95 & 7.15 \\
\hline 1 & $\begin{array}{l}\text { S1 } \\
\text { Legowo } 2: 1\end{array}$ & $4.95 \mathrm{a}$ & 0 & $2.2^{*}$ \\
\hline 2 & S2 Legowo $4: 1$ & $7.15 \mathrm{~b}$ & $2.2^{*}$ & 0 \\
\hline LSD $=1.50$ & \multicolumn{3}{l}{} \\
\hline
\end{tabular}

Explanation: The numbers followed by the same letter on the same row or column is not different significant according to Least Significant Difference Test at 5\% level

Tabel 2 The comparison between main plot (two plant systems) to subplot (biochar application $\mathrm{B} 1 / 22.5$ ton/ha).

\begin{tabular}{|l|l|l|l|l|}
\hline \multirow{2}{*}{ No } & \multicolumn{1}{|c|}{ Plant Systems } & \multirow{2}{*}{ Average } & \multicolumn{1}{c|}{ S1 Legowo 2:1 } & \multicolumn{1}{c|}{ S2 Legowo 4:1 } \\
\cline { 4 - 5 } & & & \multicolumn{1}{c|}{4.95} & 7.15 \\
\hline 1 & $\begin{array}{l}\text { S1 } \\
\text { Legowo 2:1 }\end{array}$ & $5.5 \mathrm{a}$ & 0 & $0.85^{\mathrm{ns}}$ \\
\hline 2 & S2 Legowo 4:1 & $6.4 \mathrm{a}$ & $0.85^{\text {ns }}$ & 0 \\
\hline LSD $=1.50$ & \multicolumn{3}{|l}{} \\
\hline
\end{tabular}

Explanation: The numbers followed by the same letter on the same row or column is not different significant according to Least Significant Difference Test at 5\% level 
Tabel 3 The comparison between main plot (two plant systems) to subplot (biochar application $\mathrm{B} 2 / 50.5$ ton/ha).

\begin{tabular}{|l|l|l|l|l|}
\hline \multirow{2}{*}{ No } & \multirow{2}{*}{ Plant Systems } & \multirow{2}{*}{ Average } & S1 Legowo 2:1 & S2 Legowo 4:1 \\
\cline { 4 - 5 } 1 & $\begin{array}{l}\text { S1 } \\
\text { Legowo 2:1 }\end{array}$ & $5.4 \mathrm{a}$ & 0 & 7.95 \\
\hline 2 & S2 Legowo 4:1 & $6.25 \mathrm{~b}$ & $0.85^{\text {ns }}$ & $0.85^{\text {ns }}$ \\
\hline LSD $=1.50$ & \multicolumn{3}{l}{0} \\
\hline
\end{tabular}

Explanation: The numbers followed by the same letter on the same row or column is not different significant according to Least Significant Difference Test at 5\% level

The result of F-test showed that the treatment of planting system and biochar application had a significant effect on wet harvest weight, but it did not show any real effect on the interaction between cropping system treatment and biochar application for research parameter of shoot wet weight.

The results showed significant differences in planting system on shoot wet weight for biochar application B0 on the table 1 (2.2) and showed no significant effect for biochar application on planting system in B1 (table 2) (0.85) and B2 (table 3) (0.85)

\subsection{Shoot Dry Weight}

Tabel 4 The comparison between main plot (two plant systems) to subplot (biochar application)

\begin{tabular}{|l|l|l|l|l|}
\hline \multirow{2}{*}{ No } & \multirow{2}{*}{ Plant Systems } & \multirow{2}{*}{ Average } & S1 Legowo 2:1 & S2 Legowo 4:1 \\
\cline { 4 - 5 } & & 4.48 & 6.45 \\
\hline 1 & S1 Legowo 2:1 & $4.48 \mathrm{a}$ & 0 & $1.97^{*}$ \\
\hline 2 & S2 Legowo 4:1 & $6.45 \mathrm{~b}$ & $1.97^{*}$ & 0 \\
\hline LSD $=1.13$ & \multicolumn{3}{l}{} \\
\hline
\end{tabular}

Explanation: The numbers followed by the same letter on the same row or column is not different significant according to Least Significant Difference Test at 5\% level

Tabel 5 The comparison between main plot (two plant systems) to subplot (biochar application $\mathrm{B} 1 / 25.5$ ton/ha).

\begin{tabular}{|l|l|l|l|l|}
\hline \multirow{2}{*}{ No } & \multirow{2}{*}{ Plant Systems } & \multirow{2}{*}{ Average } & S1 Legowo 2:1 & S2 Legowo 4:1 \\
\cline { 4 - 5 } & & & 4.48 & 6.45 \\
\hline 1 & S1 Legowo 2:1 & $4.65 \mathrm{a}$ & 0 & $0.6^{\text {ns }}$ \\
\hline 2 & S2 Legowo 4:1 & $5.25 \mathrm{a}$ & $0.6^{\mathrm{ns}}$ & 0 \\
\hline LSD $=1.13$ & \multicolumn{3}{l}{} \\
\hline
\end{tabular}

Explanation: The numbers followed by the same letter on the same row or column is not different significant according to Least Significant Difference Test at 5\% level

Tabel 6 The comparison between main plot (two plant systems) to subplot (biochar application

\begin{tabular}{|l|l|l|l|l|}
\hline \multirow{2}{*}{ No. } & \multirow{2}{*}{ Plant Systems } & \multirow{2}{*}{ Average } & S1 Legowo 2:1 & S2 Legowo 4:1 \\
\cline { 4 - 5 } & & & 4.9 & 5.65 \\
\hline 1 & S1 Legowo 2:1 & $4.9 \mathrm{a}$ & 0 & $0.75^{\text {ns }}$ \\
\hline 2 & S2 Legowo 4:1 & $5.65 \mathrm{a}$ & $0.75^{\text {ns }}$ & 0 \\
\hline LSD $=1.13$ & \multicolumn{3}{|l}{} \\
\hline
\end{tabular}


Explanation: The numbers followed by the same letter on the same row or column is not different significant according to Least Significant Difference Test at 5\% level.

The result of F-test showed that planting system had the significant effect on shoot dry weight research parameter while biocar application had no significant effect on shoot dry weight, and interaction between planting system treatment and biochar application did not show the real effect for shoot dry weight parameter.

The results showed that planting system treatment to shoot dry weight significantly affected biochar application B0 on the table 4 (1.97) and showed no significant effect for biochar application on planting system in B1 (table 5) (0.6) and (table 6) B2 (0.75).

\section{Conclusion}

The results showed that the treatment of biochar increased the shoot wet weight but had no significant effect on shoot dry weight. The treatment of planting systems had the significant effect on shoot wet weight and shoot dry weight.

\section{References}

1. Mawardiana, Sufardi, and E. Husen, The Effect of biochar residue and NPK fertilizer to nitrogen dynamics, soil chemical character and paddy yield (Oryza sativa L.) on third planting season. Jurnal Manajemen Sumberdaya Lahan 2 (3). pp. 255-260, (2013)

2. J. Pramono, Study on the use of organic material on paddy field. J. A 6 (1). pp 11-14, (2004)

3. Rostaliana, P., Prawito, P., dan Turmudi, E, Utilization of biochar for land quality improvement with the indicators of maize and gogo paddy on land and fire fuel system. J. N. E. M. R 1, No 3, (2012)

4. Czimczik CI, Masiello CA, Controls on black carbon storage in soils. G.B.C 21 : GB3005, (2007)

5. Jeffery S, Verheijen FGA, van der Velde M, Bastos AC, A quantitative review of the effects of biochar application to soils on crop productivity using meta-analysis. J. A. E. E 144. pp175-187, (2011)

6. Oktalaseva, W., Hermansah., dan Nurwanita, E. P, The characteristics of soil fertility and nutrient potential from organic materials waste paddy harvest at some locations in west sumatera. Agriculture Faculty, Andalas University, Padang, (2013)

7. Mujisihono, R and T. Santosa, Direct seed crop technology and Legowo Planting System. Paper was presented on Engineering Production System of Rice Commodities and Palawija Seminar. Agriculture Institution, Province D.I Yogyakarta, (2001)

8. Ikhwani, Pratiwi GR, Paturrohman E, and Makarim AK. 2013, Increasing Rice Productivity through the Implementation of Jajar Legowo Planting System. J.P.F.S 8, No 2, (2013)

9. Research Centre for Agricultural Technology Jambi, Legowo planting system for paddy, (2013) 